\title{
Cholesterol Granuloma of the Maxillary Sinus
}

\author{
Cinthya Bessa da Motta ALMADA ${ }^{1}$ \\ Debora Rodrigues FONSECA ${ }^{1}$ \\ Rachel Rego VANZILLOTTA ${ }^{1}$ \\ Fábio Ramôa PIRES ${ }^{2}$
}

\begin{abstract}
${ }^{1}$ Department of Oral and Maxillofacial Surgery, Getúlio Vargas State Hospital, Rio de Janeiro, RJ, Brazil
${ }^{2}$ Department of Oral Pathology, Dental School, State University of Rio de Janeiro, Rio de Janeiro, RJ, Brazil
\end{abstract}

\begin{abstract}
Cholesterol granuloma (CG) is a foreign body reaction to the deposition of cholesterol crystals, usually found in association to chronic middle ear diseases, being highly uncommon in the paranasal sinuses. This article reports a case of CG in the maxillary sinus of a 22year-old man, manifesting as a swelling on the right maxilla associated with pain and nasal obstruction. Computed tomography (CT) imaging showed complete opacification of the right maxillary sinus with cortical bone expansion and destruction. Incisional biopsy showed a solid mass filling the sinus and histological examination showed foreign body reaction to cholesterol crystals. The microscopic findings associated to tooth vitality, CT images and absence of a cavity during the surgical procedure were compatible with the diagnosis of CG of the maxillary sinus. Complete surgical excision of the mass under general anesthesia was suggested, but the patient did not return to conclude the treatment. CG must be included in differential diagnosis of diseases that cause opacification on the paranasal sinuses, especially sinusitis, and cystic and tumoral lesions.
\end{abstract}

Key Words: cholesterol, granuloma, maxillary sinus.

\section{INTRODUCTION}

Cholesterol granuloma (CG) can be found in several areas of the body, including middle ear (its most common site, usually associated to chronic middle ear diseases), mastoid process, breast, sella turcica, pontocerebelline angle, testis, lungs, brain, kidneys and in the apex of the temporal bone pyramid (1). It has been considered a rare entity in the maxillary sinus, with less than 40 reported cases in the English-language literature up to 2007 , since its first description in this anatomic site by Graham and Michael in 1978 (1-7).

The purpose of this paper is to report a case of CG in the maxillary sinus of a young adult, emphasizing the rarity and differential diagnosis of this lesion.

\section{CASE REPORT}

A 22-year-old male entered the Department of Oral and Maxillofacial Surgery of Getúlio Vargas State
Hospital, Rio de Janeiro, Brazil, presenting symphisal mandibular fracture caused by a gunshot. Intraoral examination showed, in addition to the fracture, a tender painful swelling on the right maxilla with fistula and pain, associated to nasal obstruction. His right maxillary teeth were vital and presented no mobility. Computed tomography (CT) findings showed the mandible fracture and complete opacification of the right maxillary sinus, with expansion and focal destruction of the cortical bone, extending into the right nasal cavity (Fig. 1).

The patient had his mandible fracture reduced and stabilized with rigid fixation, and an incisional biopsy was performed through the vestibular area of the right maxilla, showing a yellowish rubbery solid tissue (Fig. 2). The specimen was immersed in 10\% formalin solution and sent to the Oral Pathology Laboratory of the Dental School of the State University of Rio de Janeiro, Brazil, for histopathological analysis. Fivemicrometer-thick histological sections stained with hematoxylin and eosin showed a connective tissue 
containing extensive areas of cholesterol clefts, surrounded by multinucleated foreign body giant cells, chronic inflammatory cells, macrophages, foam cells and hemosiderin (Figs. 3 and 4).

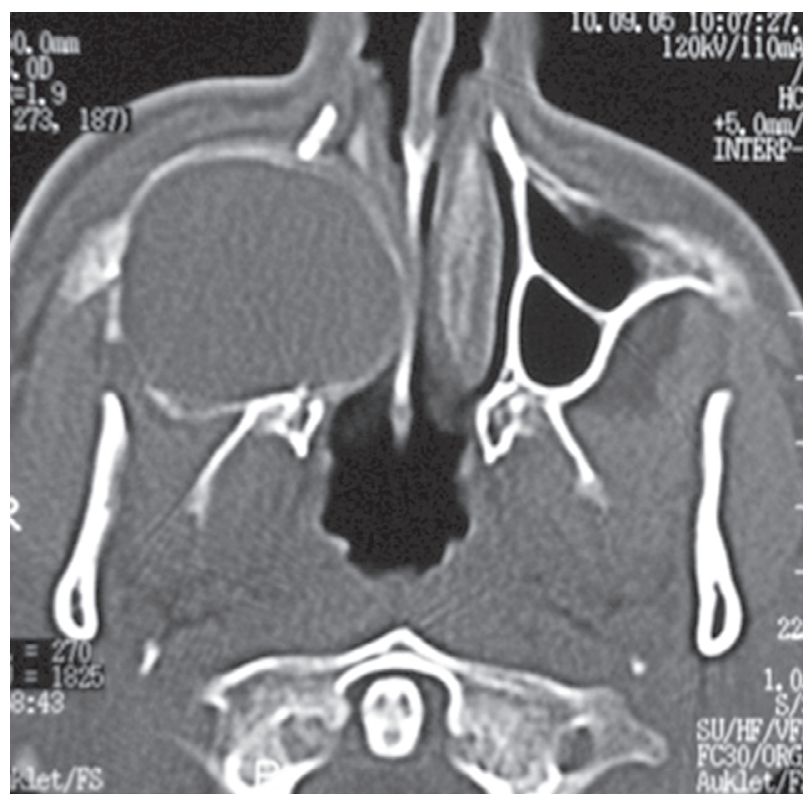

Figure 1. Axial CT showing right maxillary sinus opacification, with cortical bone expansion and destruction, extending into the right nasal cavity.

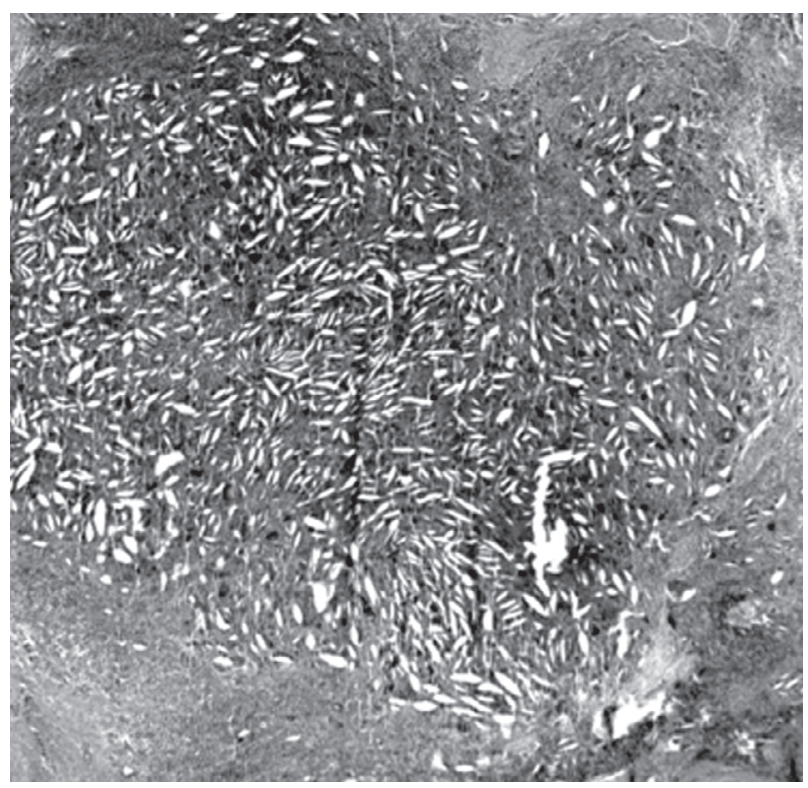

Figure 3. Histopathology of CG showing a dense connective tissue containing cholesterol clefts and an intense chronic inflammatory infiltrate. HE. (original magnification $\times 20$ ).
The microscopic findings associated to tooth vitality, CT images and absence of a cavity during the surgical procedure were all compatible with the diagnosis of maxillary sinus CG. Complete surgical excision of the

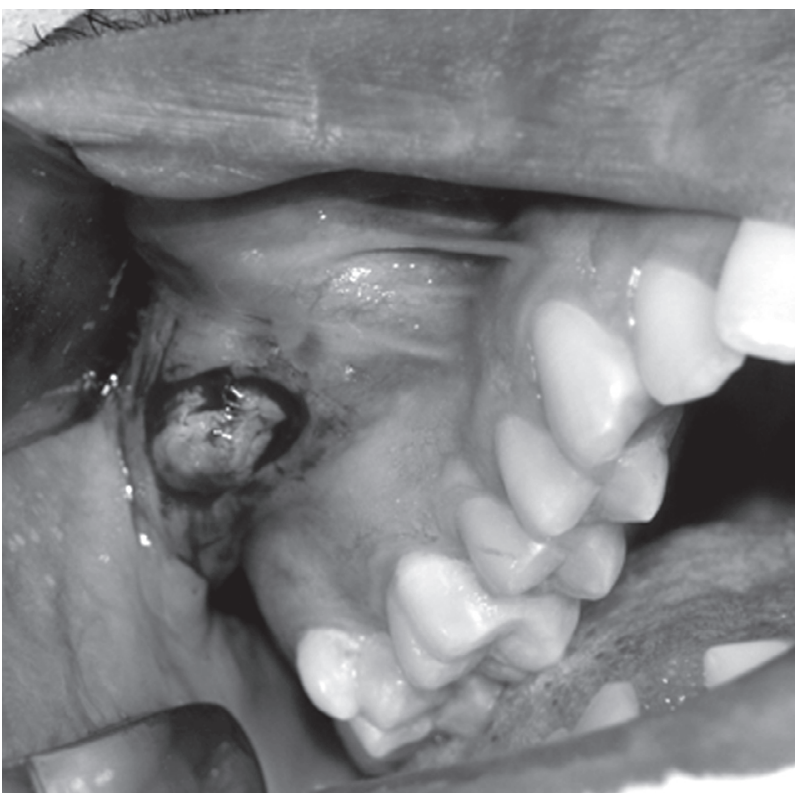

Figure 2. Clinical aspect of the lesion, which showed a yellowish rubbery solid tissue during incisional biopsy.

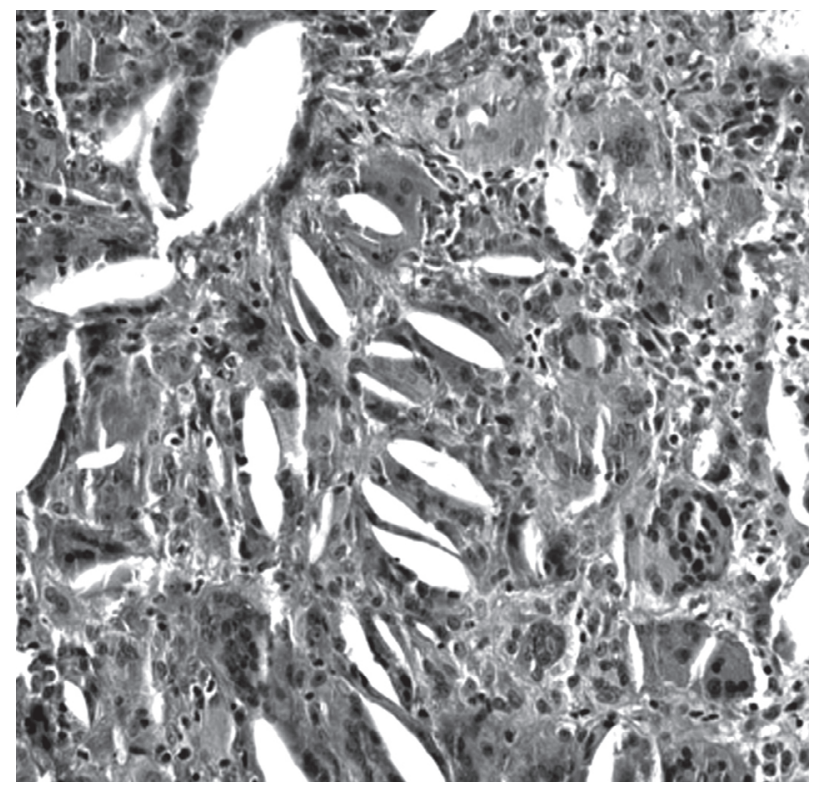

Figure 4. Detail of the histopathology of CG highlighting the cholesterol clefts surrounded by multinucleated foreign body giant cells. HE. (original magnification $\times 20$ ). 
mass under general anesthesia was suggested, but the patient did not return to conclude the treatment.

\section{DISCUSSION}

There is a prominent male gender predilection for $\mathrm{CG}$, with a male to female ratio of $3: 1$, and it is more common in middle-aged patients (mean age $=38$ years old; age range from 27 to 56 years) $(1,4)$. The patient of the present study, though, was an young adult. The patients usually present unspecific symptoms, such as headache, facial pain, nasal discharge and sinusitis; however, the most suggestive symptom is a clear yellowish rhinorrhea $(1,6,8)$. Nasal obstruction and intraoral swelling, as evidenced in the present case, are not commonly found in association to maxillary sinus CG $(6,8)$.

Possible mechanisms involved in the pathogenesis of maxillary sinus CG are impairment of drainage, disturbed ventilation and hemorrhage into the sinus with hemolysis (5). The source of cholesterol is considered to be the cell membrane of erythrocytes destroyed during bleeding, that precipitates in a crystalline form, due to inadequate drainage (9). These crystals stimulate foreign body reaction that causes migration of leukocytes and macrophages, which will further give rise to foreign body giant cells (5). Additionally, connective tissue degeneration due to reduction of the ventilation, caused by osteomeatal complex obstruction by trauma and inflammatory products, can also contribute to form cholesterol crystals. Due to its pathogenesis, maxillary sinus CG is often associated to a history of rhinitis, sinusitis, trauma and paranasal sinus surgery, especially because they can cause local bleeding focuses (4,6-9).

The most common radiographic findings of maxillary sinus CG include opacification of the maxillary sinus, with cystic arrangement or soft tissue density, usually well-defined by sclerotic cortical bone, although bone expansion and erosion can be observed $(1,8)$. Calcification foci are rare (4,6). Differential diagnosis of CG should include allergic and inflammatory sinusal diseases, mucoceles, pyomucoceles, and sinusal odontogenic and non-odontogenic cysts and tumors $(6,9)$. Therefore, CT images are also important to complement diagnosis and treatment planning. In the present case, an axial CT section of the right maxillary sinus revealed that the mass produced expansion and erosion of the cortical plates, as well as extension into the right nasal cavity with switching of the nasal septum. Except for the destruction of the sinus walls described in some cases, the symptoms, clinical and radiographic findings, can be misdiagnosed as chronic sinusitis. These features highlight that, as the final diagnosis depends on histological analysis, CG should also be kept in mind as differential diagnosis of unilateral maxillary sinus opacification.

CG is considered a non specific histopathological reaction to cholesterol crystals rather than a clinical or pathological entity. It is microscopically characterized by the presence of cholesterol clefts surrounded by multinucleated foreign body giant cells, in the presence of neovascularization and hemosiderin within a fibrous connective stromal tissue (10). Foam cells, macrophages and chronic inflammatory cells are embedded in the fibrous granulation tissue, and bony fragments, plasma and respiratory epithelial remnants may be also found $(8,9)$. Histopathological analysis is essential for the final diagnosis of maxillary sinus CG, as its clinical and radiographic characteristics are non-specific, and each sinonasal diseases require specific approach $(1,6,9)$. Apart from this, there is also the possibility of secondarily or primarily inflamed odontogenic lesions that show a foreign body reaction to cholesterol crystals in their capsule, possibly extending to the maxillary sinuses due to anatomical continuity.

The treatment of choice for maxillary sinus CG is surgical excision, usually through a Caldwell-Luc approach, but the transnasal endoscopic technique has also been reported to be useful $(1,4,8)$. Prognosis is good and recurrences are rare with effective treatment.

In conclusion, $\mathrm{CG}$ is an uncommon tissue reaction to cholesterol crystals on the maxillary sinus and is frequently associated to chronic sinusal diseases, trauma and surgery in the area, which may cause focal bleeding. Because its signs and symptoms are unspecific, CG should be considered in the differential diagnosis of other sinusal lesions, and histopathological analysis is essential for a correct final diagnosis.

\section{RESUMO}

Granuloma de colesterol (GC) é uma reação de corpo estranho a deposição de cristais de colesterol, usualmente encontrado em associação com doenças crônicas do ouvido médio, sendo bastante incomum nos seios paranasais. O objetivo deste artigo é relatar um caso de GC no seio maxilar de um homem de 22 anos de idade, manifestando-se como aumento de volume na 
maxila direita, associado a dor e obstrução nasal. Cortes de tomografia computadorizada (TC) mostraram opacificação completa do seio maxilar direito com expansão e destruição do osso cortical. A biópsia revelou uma massa sólida ocupando o seio maxilar e o exame histológico mostrou uma reação de corpo estranho aos cristais de colesterol. Os achados microscópicos associados à vitalidade dos dentes, imagens em TC e ausência de cavidade durante o procedimento cirúrgico foram compatíveis com o diagnóstico de GC do seio maxilar. A excisão cirúrgica completa da massa sob anestesia geral foi sugerida, mas o paciente não retornou para concluir o tratamento. O GC deve ser incluído no diagnóstico diferencial das doenças que causam opacificação dos seios paranasais, especialmente as sinusites e lesões císticas e tumorais.

\section{REFERENCES}

1. Chao TK. Cholesterol granuloma of the maxillary sinus. Eur Arch Otorhinolaryngol 2006;263:592-597.

2. Graham J, Michaels L. Cholesterol granuloma of the maxillary antrum. Clin Otolaryngol Allied Sci 1978;3:155-160.

3. Kikuchi T, So E, Ishimaru K, Miyabe Y, Abe K, Kobayashi T. Endoscopic sinus surgery in cases of cholesterol granuloma of the maxillary sinus. Tohoku J Exp Med 2002;197:233-237.
4. Ko MT, Hwang CF, Kao YF, Lui CC, Huang CC, Peng JP Cholesterol granuloma of the maxillary sinus presenting as sinonasal polyp. Am J Otolaryngol 2006;27:370-372.

5. Milton CM, Bickerton RC. A review of maxillary sinus cholesterol granuloma. Br J Oral Maxillofac Surg 1986;24:293299.

6. Ramani P, Murugesan K, Chandrasekar T, Anuja N. Cholesterol granuloma of maxillary sinus. Int J Oral Maxillofac Surg 2006;35:1063-1065.

7. Sarioglu S, Pabuççuoglu U, Arzu Topal N. Cholesterol granuloma and aspergilloma of the maxillary sinus. Eur Arch Otorhinolaryngol 2001;258:74-76.

8. Leon ME, Chavez C, Fyfe B, Nagorsky MJ, Garcia FU. Cholesterol granuloma of the maxillary sinus. Arch Pathol Lab Med 2002;126:217-219.

9. Bella Z, Torkos A, Tiszlavicz L, Iván L, Jóri J. Cholesterol granuloma of the maxillary sinus resembling an invasive, destructive tumor. Eur Arch Otorhinolaryngol 2005;262:531533.

10. Kunt T, Ozturkcan S, Egilmez R. Cholesterol granuloma of the maxillary sinus: six cases from the same region. J Laryngol Otol 1998;112:65-68.

Accepted April 1, 2008 